\title{
Process Optimization and Characterization of Sorghum Based Extruded Product
}

\author{
Mahesh B. Zamre, Manisha V. Jadhav and Uday S. Annapure \\ Food Engineering and Technology Department, Institute of Chemical Technology (formerly UDCT), Matunga (E), Mumbai 400019, \\ India
}

Received: May 7, 2012 / Published: July 20, 2012.

\begin{abstract}
Expanded snacks made up of corn, wheat and rice is very popular because of their texture. Sorghum is one of the important cereals, which is not so far studied well for extrusion processing. Due to presence of high amount of starch (56\%-73\%): sorghum could be the good candidate for manufacturing of expanded snacks. The extruded products obtained using extrusion conditions such as feed moisture content (12\%-16\%), die temperature (150-190 $\left.{ }^{\circ} \mathrm{C}\right)$, screw speed (150-210 rpm) and feed rate $(50-70$ $\mathrm{g} \mathrm{min}^{-1}$ ) are further characterized by analyzing bulk density, expansion ratio, water absorption index (WAI), water solubility index (WSI), textural properties, color and sensory evaluation. Increase in feed moisture content resulted in extrudates with gradual increase in density, WAI and hardness and decrease in expansion, WSI, crispness and whiteness. Higher barrel temperature reduced the extrudate expansion, bulk density and hardness and increased the WSI and crispness of the extrudates. The most acceptable product is obtained using response surface methodology (RSM).
\end{abstract}

Key words: Extrusion, sorghum, physical properties, response surface methodology.

\section{Introduction}

Grain sorghum is the third most important cereal crop grown in the United States and the fifth most important cereal crop grown in the world. Nigeria is the world's largest producer of grain sorghum followed by United States and India. It is a leading cereal grain produced in Africa and is an important food source in India. India is currently positioned as the number three in production with $11.7 \%$ of world sorghum production and the fourth exporter of sorghum in the world market. In many parts of the world sorghum has traditionally been used for preparing many food products such as porridge, unleavened bread, cookies, cakes, couscous and malted beverages. Either whole grains or flour is being used in making various traditional products. The most important property of sorghum is that its gluten free and hence may be more suitable for the gluten

Corresponding author: Uday S. Annapure, Ph.D., associate professor, research fields: extrusion processing-process and product development. E-mail: us.annapure@ictmumbai.edu.in. intolerance people. Some of the sorghum varieties are also rich in antioxidants [1, 2].

Extrusion cooking is used worldwide for the production of expanded snack foods, modified starches, ready to eat cereal foods, pet foods and porridge [1-3]. This unit operation consists of converting biopolymer-based raw materials into viscoelastic melts, that is, the transport mechanism through the extruder changes along the screw from solid flow to fluid flow. As a consequence of the pressure built up during fluid flow, high shear stresses are developed, which cause structural transformations in the material. Starch dextrinization [4, 5] and amylopectin breakdown due to mechanical shear [6] have been observed during low moisture, high shear single screw extrusion. Starch solubilization [7, 8] macromolecular degradation of amylose and amylopectin [9, 10], and reduction of high molecular weight polysaccharide [11] were reported during twin screw extrusion. Extrusion variables, composition of feed material, particle size 
distribution and additives, significantly affect extrusion parameters and product properties [1, 8, 12].

The extrusion-cooking of cereal-based products has been extensively studied during the last three decades. Product quality can vary considerably depending on the extruder type, screw configuration, feed moisture, and temperature profile in the barrel session, screw speed and feed rate [13]. Various studies have been done on the extrusion of corn, rice, wheat, barley, amaranth, chick pea, and their combinations, but less literature is available on extrusion processing of sorghum. The objective of this research is to explore the possibilities of grain sorghum for the development of extruded products and to study the effect of extrusion conditions on structural and functional properties of sorghum extrudate using response surface methodology.

\section{Materials and Methods}

\subsection{Materials}

Three selected varieties of sorghum namely PVK400, PVK 801, and PVK809 were procured from Sorghum Research Center, Marathwada Agricultural University, Parbhani, India. All chemicals and reagents used in this study were of analytical grade.

\subsection{Methods}

\subsubsection{Proximate Composition}

The grains were finely ground using a laboratory Cyclotec mill before carrying out proximate analysis. Standard methods of AOAC were used to determine: moisture by the hot air oven method [14]; protein by Kjeldahl nitrogen $(\mathrm{N} \times 6.25)$ [15]; ash using muffle furnace [15] and crude fat [15] by $16 \mathrm{~h}$ extraction with petroleum ether. Starch was determined using the enzymatic method [16] of amylase/amyloglucosidase. Fiber analysis was also done using the enzymatic method [15].

\subsubsection{Extrusion Cooking}

The extrusion cooking was carried out using Brabender Single Screw Extruder (Model No. 823500, Germany), having a screw with a compression ratio of
2:1 and L/D ratio of 20:1. The samples were ground to coarse size and were subjected to conditioning by addition of water to obtain desired moisture equilibrium in feed material. The samples were conditioned for $24 \mathrm{~h}$ prior to extrusion. The process conditions were optimized using response surface methodology. The processing conditions like feed moisture, die temperature, screw rpm and feed rate were varied over five levels. The feed moisture was varied from $12 \%$ to $16 \%$, die temperature from $150{ }^{\circ} \mathrm{C}$ to $190{ }^{\circ} \mathrm{C}$, screw speed from 150 to $210 \mathrm{rpm}$ and feed rate from 50 to $70 \mathrm{~g} \mathrm{~min}^{-1}$. Finally, the extrudates were dried for a period of $2 \mathrm{~h}$ at $50{ }^{\circ} \mathrm{C}$ to the desired moisture content of $4 \%$ and the effect of these conditions on physical properties of extrudates were determined.

\subsubsection{Expansion Ratio}

The expansion ratio was determined as the ratio of diameter of extrudates to the diameter of the die. Ten random readings were taken for each sample and their average was taken as the mean diameter of the extrudate.

\subsubsection{Bulk Density, True Density and Porosity}

The bulk density was calculated by measuring the actual dimensions of the extrudates as suggested by Launay and Lisch [17].

\subsubsection{Textural Characteristics}

The textural characteristics of the extrudates were determined using TAXT2i texture analyzer, Stable Micro Systems, Ltd. in Godalming, Surrey UK. The measured parameters include hardness and crispness. All measurements were done using $2 \mathrm{~mm}$ cylindrical probe.

\subsubsection{Color Values}

The color of extrudates was determined using Hunter Labscan colorimeter (Hunter Associate Laboratory Inc. Reston, VA). The samples were ground before taking measurement to pass through 40 micron sieve.

2.2.7 Water Absorption Index (WAI) and Water Solubility Index (WSI)

The WSI and WAI of the extrudates were 
determined using the method of Anderson et al. [18].

\subsubsection{Sensory Evaluation}

The sensory analysis was done using a nine point hedonic scale with score 1 indicating dislike extremely and score 9 indicating like extremely. The average value was taken as the sensory score for each sample.

\subsubsection{Statistical Optimization Using RSM}

The process was optimized for the maximum values of expansion ratio, color values and sensory ratings for extrudates. The initial experiments carried out showed that good expansion ratio could be obtained at the feed moisture levels of $13 \%-15 \%$, die temperature of 160-180 ${ }^{\circ} \mathrm{C}$, screw speed of 160-190 rpm and feed rate $\left(\mathrm{g} \mathrm{min}^{-1}\right)$. Based on this preliminary experimental data, a randomly assigned five level design $(-2,-1,0,1,2)$ was employed for the optimization.

\section{Results and Discussion}

\subsection{Proximate Analysis}

Starch is the most influential component of flour affecting the structural and functional properties of extrudates. All three varieties of sorghum (PVK400, PVK801 and PVK 809) contain fat 3.8\%, 3.5\% and 3\%; protein $8.9 \%, 8.8 \%$ and $8.3 \%$; and are fairly rich in starch, with sorghum variety PVK801 being highest (67\%) with respect to starch content. Also they are a good source of proteins and fibers.

\subsection{Screening of Varieties}

All three varieties were extruded using same experimental conditions of feed moisture 14\%, barrel temperature $180^{\circ} \mathrm{C}$, screw speed $180 \mathrm{rpm}$ and feed rate $60 \mathrm{~g} \mathrm{~min}^{-1}$. The results of these experiments are given in Table 1. The sensory evaluation showed that extrudate PVK801 was the most acceptable. The expansion ratio for extrudates of all three varieties was almost the same. The extrudate of PVK801 had the lowest bulk density and hardness and the highest porosity. This gives the extrudate more chewable and favored. The high bulk density of PVK801 can be attributed to its higher starch content. Based on these results the sorghum variety PVK801 was chosen for further studies.

\subsection{Optimization Studies}

The combined effect of four different extrusion parameters (independent variables), namely, feed moisture(X1), barrel temperature(X2), screw speed(X3) and feed rate(X4), on various characteristics of extrudates were studied using a central composite factorial design of $2^{4}=16$ plus 6 centre points and $(2 \times$ $4=8$ ) star points leading to a total of 30 experiments. Second order polynomial equation was used to correlate the independent process variables, $\mathrm{Xi}$, with extrudate characteristics. The second order polynomial coefficients for each term of the equation were determined through multiple regression analysis using the Design Expert software. The model significance was analyzed by using ANOVA, i.e., analysis of variance suitable.

The Analysis of Variance (ANOVA) is important in determining the adequacy and significance of the quadratic model. There are various statistical parameters that summarize the extent of model significance such as adequate precision, $\mathrm{R}^{2}$, adjusted $\mathrm{R}^{2}$ and coefficient of the variation $(\mathrm{CV})$. Adequate precision measures the signal to noise ratio. A ratio greater than 4 indicates an adequate signal. The mathematical model is reliable with an $\mathrm{R}^{2}$ value closer to 1 . The value of adjusted $R^{2}$ value close to $R^{2}$ also suggests that model was significant. A very low value of coefficient of the variation (CV) is a clear indication of a very high degree of precision and a good deal of reliability of the experimental values. All the models showed good significance [19].

The $P$ values were used as a tool to check the significance of each of the coefficients, which, in turn, are necessary to understand the pattern of the mutual interactions between the test variables. The smaller the magnitude of the $P$, the more significant is the corresponding coefficient. Values of $P$ less than 0.05 
indicate model terms are significant. Fig. 1 shows the 3-D response plots of significant interactions for each physical property.

\subsection{Bulk Density}

The coefficient estimates and the corresponding $P$ values suggests that, among the test variables used in the study, feed moisture, barrel temperature and $\mathrm{X}_{3}$ screw speed are significant variables. $\mathrm{X}_{1}$ and $\mathrm{X}_{2}(P<$ $0.0001)$ has the largest effect on extrudate bulk density, followed by $\mathrm{X}_{3}(P<0.0160)$. The mutual interaction between $\mathrm{X}_{2}$ and $\mathrm{X}_{3}(P<0.0008), \mathrm{X}_{1}$ and $\mathrm{X}_{2}(P<$ 0.0215), $X_{1}$ and $X_{3}(P<0.0260)$ and $X_{2}$ and $X_{4}(P<$ 0.0383 ) were also found to be important.

Table 1 Characterization and sensory evaluation of extrudates prepared using three sorghum varieties viz. PVK400, PVK801 and PVK809.

\begin{tabular}{lllllll}
\hline Variety & Expansion ratio & Bulk density $\left(\mathrm{g} / \mathrm{cm}^{3}\right)$ & Porosity & Hardness $(\mathrm{g})$ & Color value & Sensory score \\
\hline PVK400 & 1.86 & 0.34 & 0.24 & 1,254 & 63.76 & 6 \\
PVK801 & 1.89 & 0.27 & 0.38 & 789 & 68.24 & 7 \\
PVK809 & 1.75 & 0.34 & 0.22 & 1,381 & 64.85 & 5.8 \\
\hline
\end{tabular}
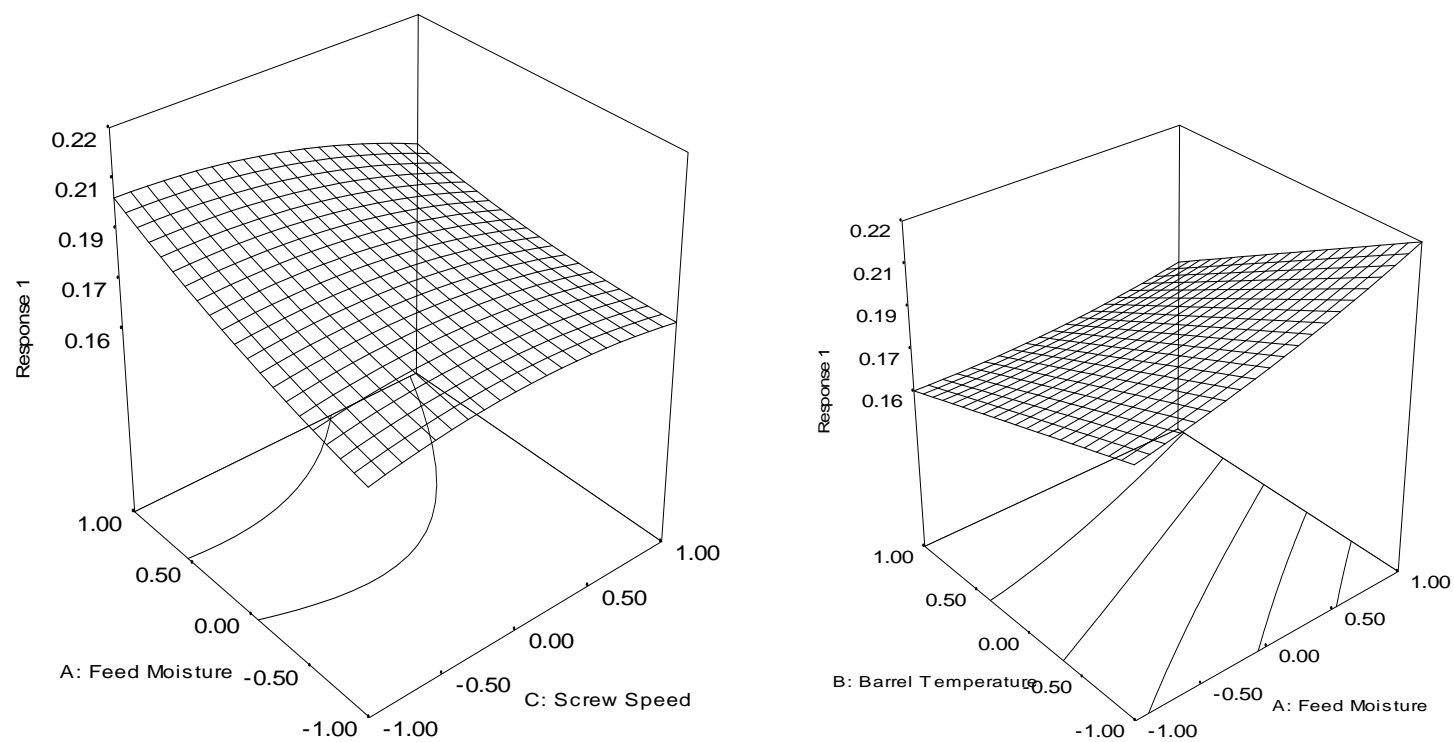

a. Bulk Density
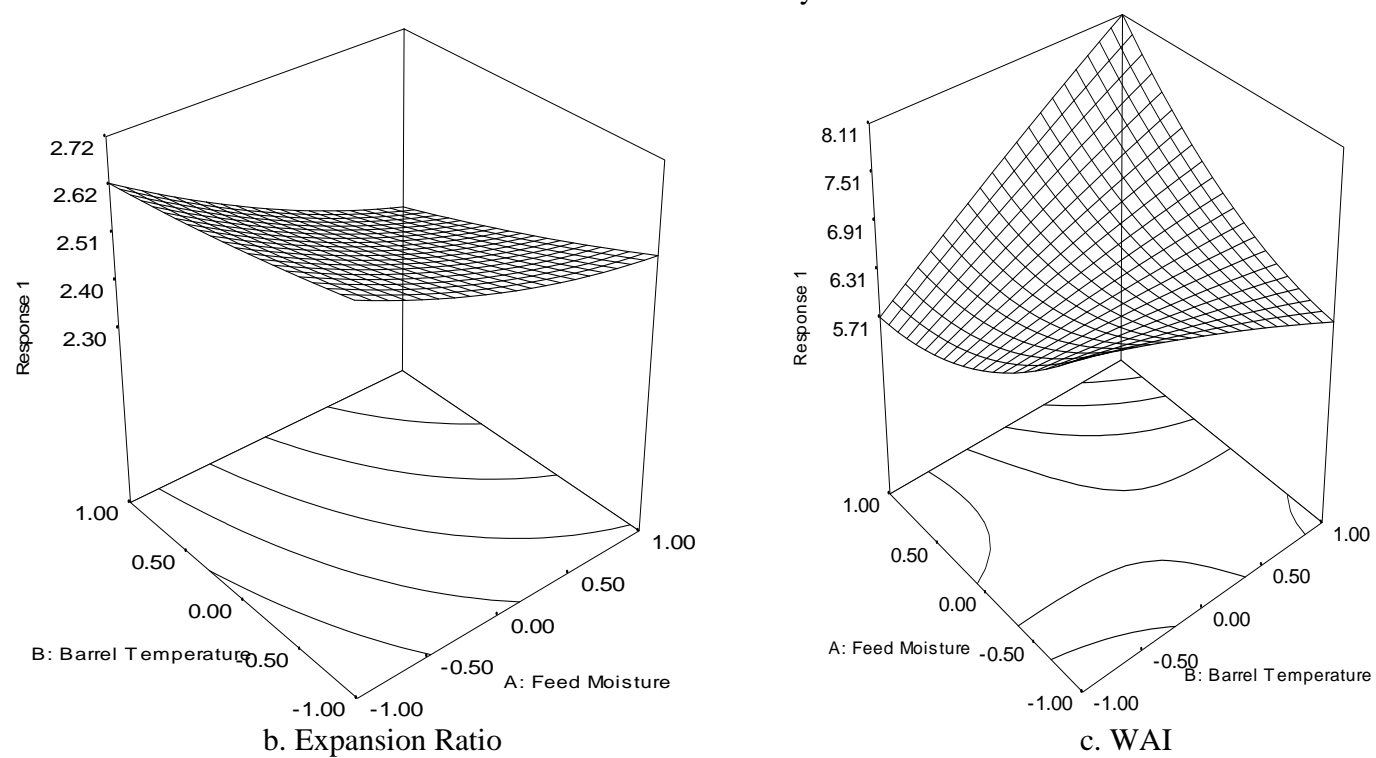

b. Expansion Ratio

c. WAI 

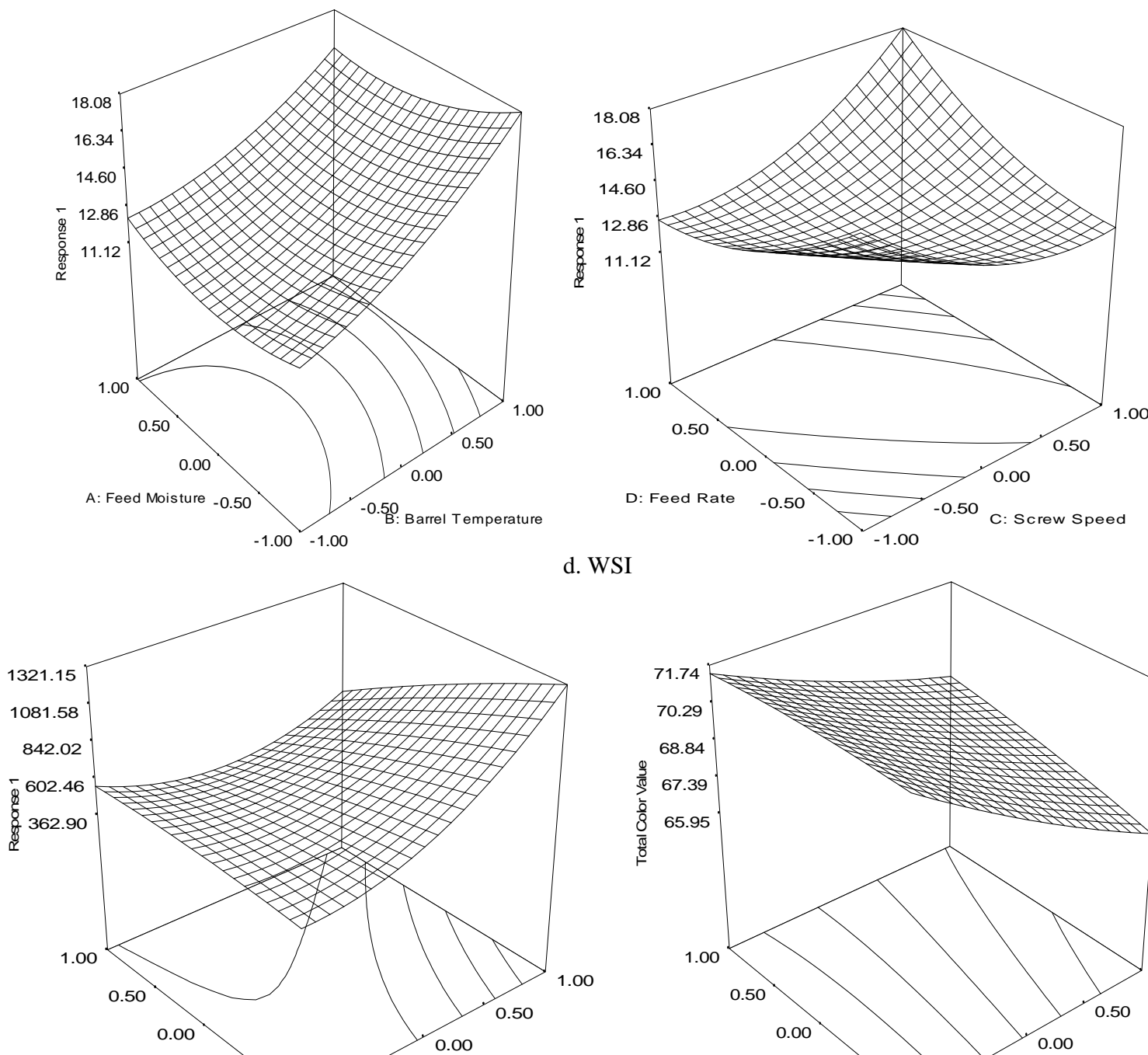

B: Barrel Temperatureo.50 -0.50 A: Feed Moisture $-1.00-1.00$

e. Hardness

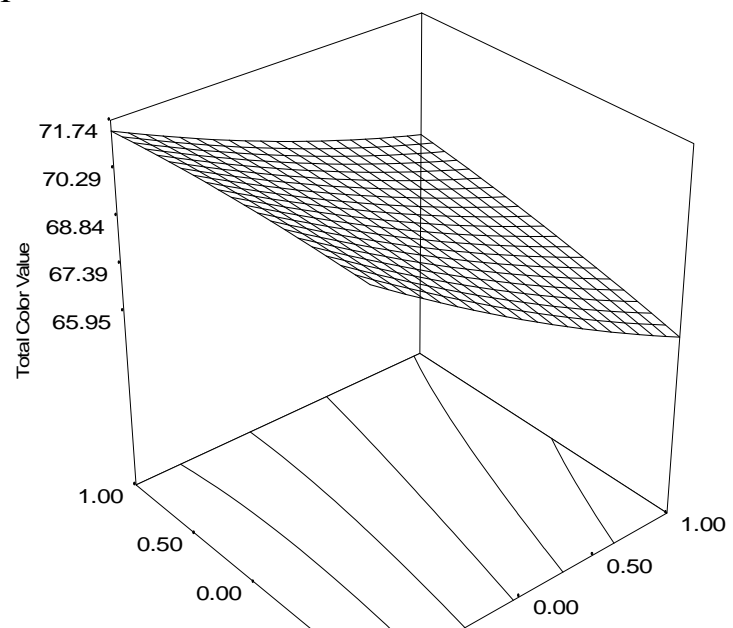

B: Barrel Temperaturg -0.50 A: Feed Moisture $-1.00-1.00$ f. Total Color
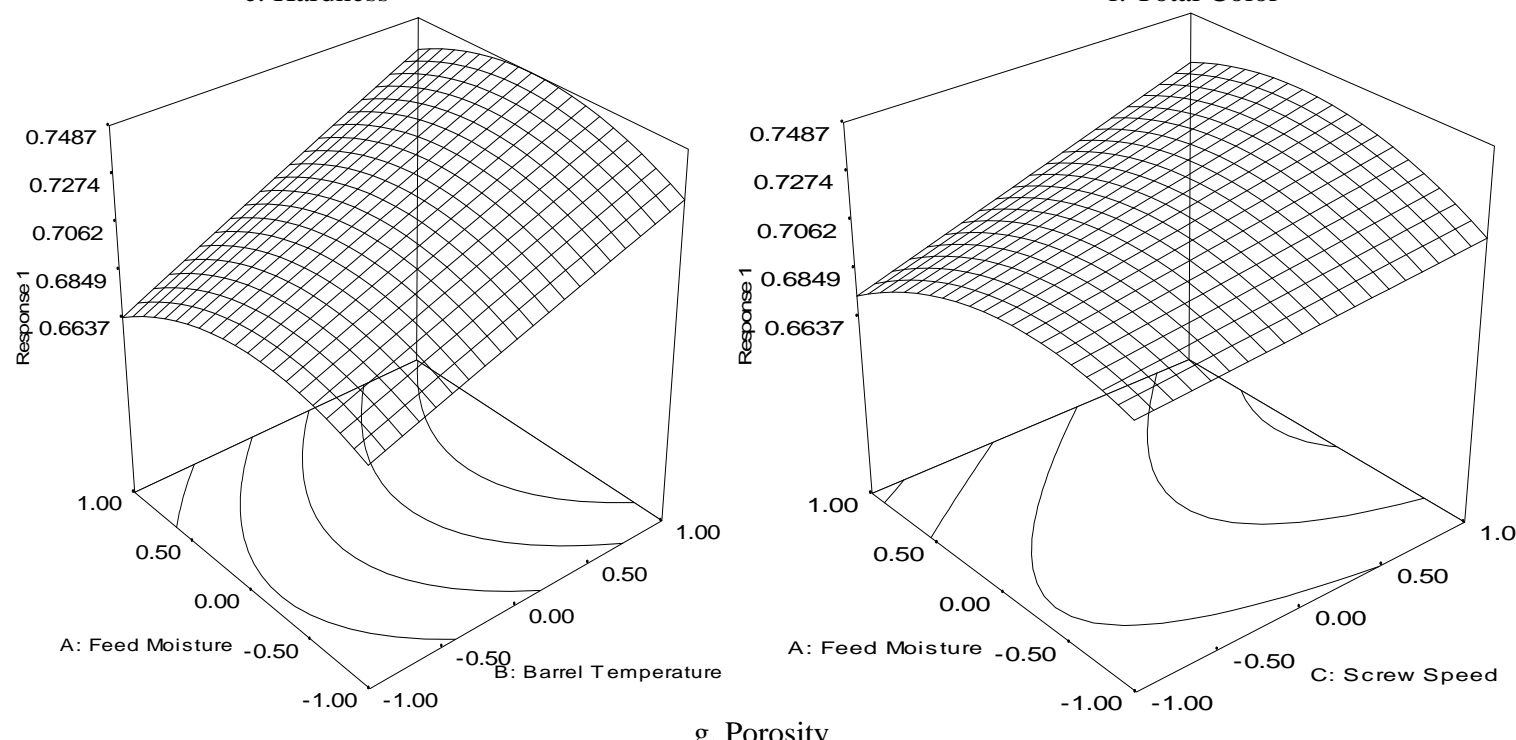

g. Porosity

Fig. 1 The 3-D response plot of significant interactions for various structural and functional variables of extrudate. 
The extrudate density was found to be most dependent on feed moisture and temperature. However, the moisture has shown positive effect, i.e., an increase in the feed moisture content resulted in a sharp increase in extrudate bulk density. The negative sign of the temperature coefficient suggests that an increase in the barrel temperature resulted in the decrease of extrudate bulk density.

\subsection{Expansion Ratio}

The coefficient estimates and the corresponding $P$ values suggest that, among the test variables only feed moisture and barrel temperature are significant process variables. $\mathrm{X}_{1}(P<0.0002)$ has the largest effect on extrudate expansion ratio, followed by $\mathrm{X}_{2}(P<0.0090)$. The mutual interaction between $\mathrm{X}_{1}$ and $\mathrm{X}_{4}(P<0.0313)$ was found to be important. The negative sign of their coefficients suggests that an increase in the values of feed moisture and barrel temperature resulted in a decrease in the expansion ratio of extrudates [20].

\subsection{Porosity}

Porosity was found to be strongly dependent upon barrel temperature $\left(\mathrm{X}_{2}\right)$ and screw speed $\left(\mathrm{X}_{3}\right) . \mathrm{X}_{2}(P<$ $0.0002)$ has the largest effect on extrudate porosity, followed by $\mathrm{X}_{3}(P<0.0153)$. Other interactions were found to be insignificant. The positive sign of their coefficients suggest that porosity increased with increasing barrel temperature and screw speed. The positive sign of screw speed $\left(\mathrm{X}_{3}\right)$ coefficient indicates that porosity increased with increasing screw speed. All other parameters were found to have less significant effect on the porosity of extrudates.

\subsection{Water Absorption Index (WAI)}

The coefficient estimates and the corresponding $P$ values suggests that, among the test variables only barrel temperature $\left(\mathrm{X}_{2}\right)$ and amongst the interactions $\mathrm{X}_{1} \times \mathrm{X}_{2}$ have significance influence on WAI of extrudate.
It was observed that the barrel temperature $\left(\mathrm{X}_{2}\right)$ has the highest coefficient and was found to have the most significant effect on the WAI of the extrudate. The positive sign of its coefficient shows that WAI of the extrudates increased sharply with the increase in the values of barrel temperature. WAI increased with increase in feed moisture and decreased with increasing screw speed. The WAI measures the volume occupied by the starch after swelling in excess water, which maintains the integrity of starch in aqueous dispersion [21].

\subsection{Water Solubility Index (WSI)}

WSI, often used as an indicator of degradation of molecular components [22], measures the degree of starch conversion during extrusion which is the amount of soluble polysaccharide released from the starch component after extrusion. WSI was found to be strongly dependent upon barrel temperature $(P<$ 0.0001). The mutual interaction between $X_{3}$ and $X_{4}(P$ $<0.0005$ ) was also found to be important.

\subsection{Hardness}

The coefficient estimates and the corresponding $P$ values suggest that feed moisture $\left(\mathrm{X}_{1}\right)$ and barrel temperature $\left(\mathrm{X}_{2}\right)$ are significant process variables. The mutual interaction between $\mathrm{X}_{1}$ and $\mathrm{X}_{2}(P<0.0194)$ was also found to be important. The positive sign of the feed moisture coefficient shows that the hardness of extrudates increased with the increase in feed moisture levels, while the negative sign of the temperature coefficient suggests that the hardness of extrudates decreased with the increase in barrel temperature. Increasing the screw speed also resulted in a decrease in the hardness. Increasing feed rate was found to have less significant effect on the hardness of the extrudates. It might due to the reduced expansion caused by the increase in moisture content [23]. The typical texture expert plot obtained for sorghum extrudates using TAXT2i texture analyzer is shown in Fig. 2. 


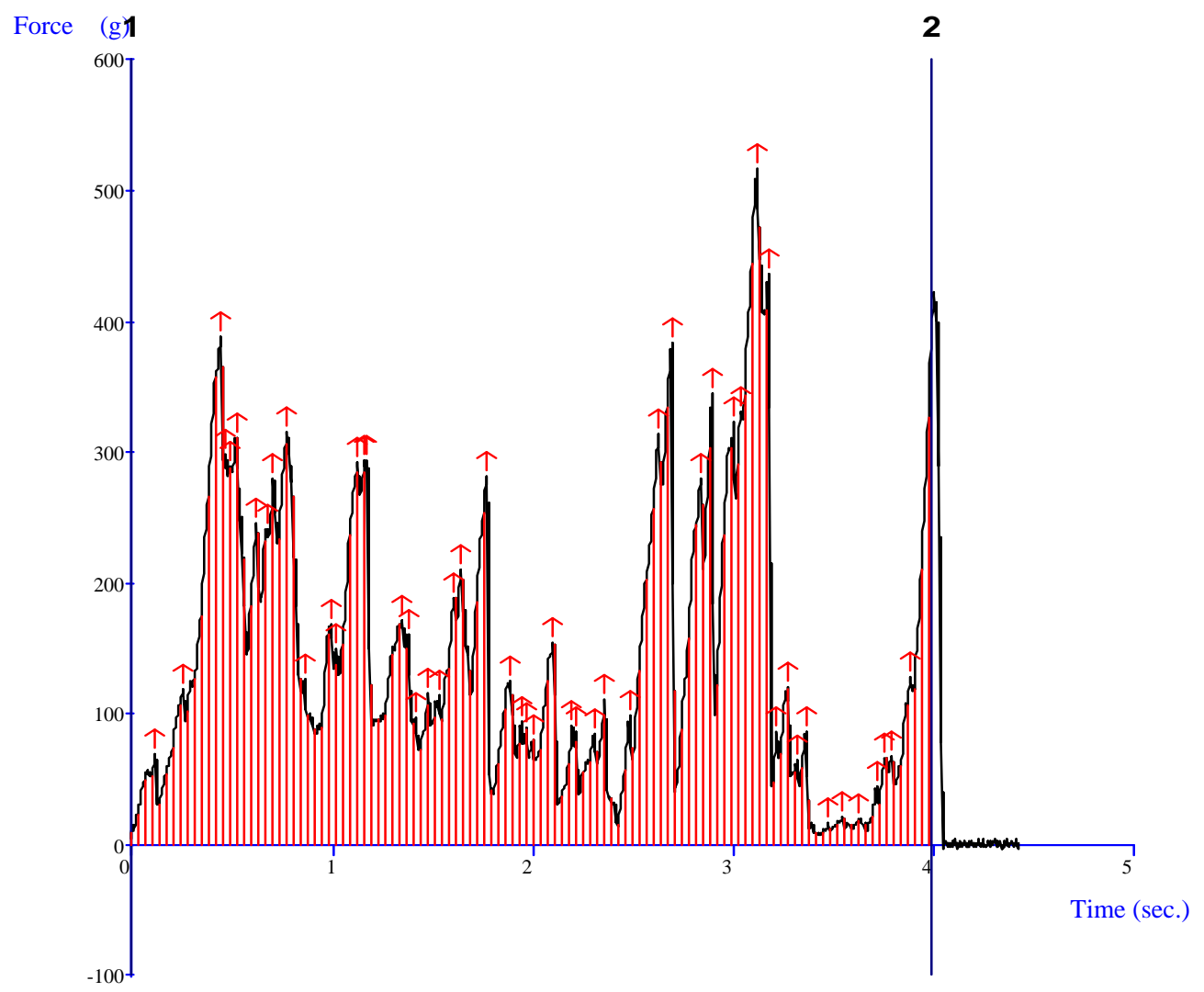

Fig. 2 Typical texture expert plot for sorghum extrudates.

\subsection{Color of Extrudates}

Feed moisture, $X_{1}(P<0.0001)$ has the largest effect on color of extrudates. The mutual interaction between $\mathrm{X}_{3}$ and $\mathrm{X}_{4}(P<0.0386)$ was also found to be important. Other interactions were found to be insignificant. The negative sign of its coefficient shows that the color (whiteness) of the extrudates decreased with the increase in feed moisture content. The barrel temperature $\left(\mathrm{X}_{2}\right)$, screw speed $\left(\mathrm{X}_{3}\right)$ and feed rate $\left(\mathrm{X}_{4}\right)$ were found to have less significant effect on the color of extrudates.

\subsection{Sensory Analysis}

From the sensory evaluation, it was very clear that the samples extruded at lower moisture levels and higher temperature levels were most acceptable in terms of extrudate characteristics [24]. Certain ranges of variables produced far better products compared to others. Very small differences in the processing conditions resulted in dramatic changes in the properties of the final product. The products that received the highest consumer acceptability are given in Table 2 along with their processing conditions and physical properties for sorghum variety PVK801. Fig. 3 shows images of extruded snacks obtained at various processing conditions. The large variation observed in visual inspection indicates the significant effect of parameters in considerations on product quality. It also suggests that process is highly non linear and also support necessity of non linear modeling and optimization methodology for the development of acceptable product.

The sensory evaluation clearly indicates that the samples with expansion ratio ranging from 2.70 to 2.90, bulk density ranging from 0.13 to 0.17 , porosity ranging from 0.67 to 0.74 , hardness ranging from 650 to $750 \mathrm{~g} \mathrm{~s}$ and with good appearance in terms of color and uniformity of shape were the most acceptable. 
Table 2 Effect of extrusion parameters on physical properties and sensory score for selected trial obtained from RSM data for sorghum variety PVK801.

\begin{tabular}{|c|c|c|c|c|c|c|c|c|c|}
\hline \multirow{2}{*}{$\begin{array}{l}\text { Trial } \\
\text { No. }\end{array}$} & \multicolumn{4}{|c|}{ Extrusion parameters } & \multicolumn{4}{|c|}{ Physical properties of extruded snacks } & \multirow{2}{*}{$\begin{array}{l}\text {-Sensory } \\
\text { score }\end{array}$} \\
\hline & $\begin{array}{l}\text { Feed } \\
\text { moisture (\%) }\end{array}$ & $\begin{array}{l}\text { Die temperature } \\
\left({ }^{\circ} \mathrm{C}\right)\end{array}$ & $\begin{array}{l}\text { Screw speed } \\
(\mathrm{rpm})\end{array}$ & $\begin{array}{l}\text { Feed rate } \\
\text { (g/min) }\end{array}$ & $\begin{array}{l}\text { Expansion } \\
\text { ratio }\end{array}$ & $\begin{array}{l}\text { Bulk density } \\
\left(\mathrm{g} / \mathrm{cm}^{3}\right)\end{array}$ & $\begin{array}{l}\text { Hardness } \\
\text { (g) }\end{array}$ & porosity color & \\
\hline 5 & 13 & 160 & 195 & 55 & 2.8947 & 0.1719 & 694 & $0.6794 \quad 71.94$ & 7.2 \\
\hline 7 & 13 & 180 & 195 & 55 & 2.8973 & 0.1373 & 635.8 & $0.7377 \quad 72.47$ & 7.2 \\
\hline 13 & 13 & 160 & 195 & 65 & 2.8433 & 0.1739 & 662.85 & $0.6804 \quad 71.95$ & 7.1 \\
\hline 17 & 12 & 170 & 180 & 60 & 2.6973 & 0.1606 & 740.05 & $0.6735 \quad 73.06$ & 8 \\
\hline
\end{tabular}

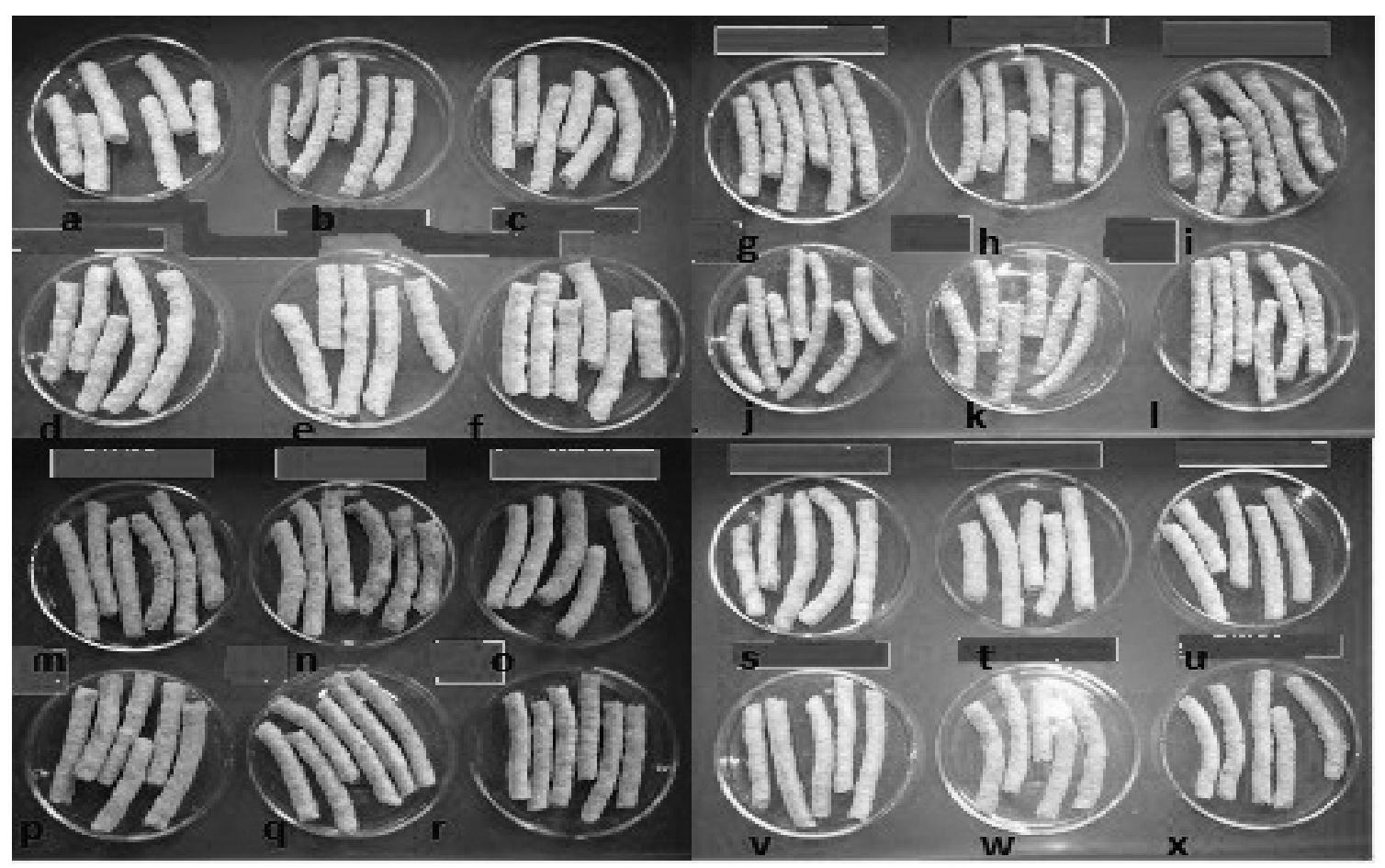

Fig. 3 Images of sorghum extrudates ready to eat products obtained at various processing parameters, where, $X_{1}$ : feed moisture (\%); $\mathrm{X}_{2}$ : barrel temperature $\left({ }^{\circ} \mathrm{C}\right) ; \mathrm{X}_{3}$ : screw speed and $\mathrm{X}_{4}$ : feed rate $(\mathrm{g} / \mathrm{min})$.

Sample code: $\quad \mathrm{a}-\mathrm{X}_{1}=12 \%, \mathrm{X}_{2}=170{ }^{\circ} \mathrm{C}, \mathrm{X}_{3}=180 \mathrm{rpm}, \mathrm{X}_{4}=60 \mathrm{~g} / \mathrm{min} ; \mathrm{b}-\mathrm{X}_{1}=16 \%, \mathrm{X}_{2}=170{ }^{\circ} \mathrm{C}, \mathrm{X}_{3}=180 \mathrm{rpm}, \mathrm{X}_{4}=60 \mathrm{~g} / \mathrm{min}$ c $-\mathrm{X}_{1}$ $=13 \%, X_{2}=160{ }^{\circ} \mathrm{C}, X_{3}=165 \mathrm{rpm}, \mathrm{X}_{4}=55 \mathrm{~g} / \mathrm{min} ; \mathrm{d}-\mathrm{X}_{1}=13 \%, \mathrm{X}_{2}=160{ }^{\circ} \mathrm{C}, \mathrm{X}_{3}=165 \mathrm{rpm}, \mathrm{X}_{4}=65 \mathrm{~g} / \mathrm{min} ; \mathrm{e}-\mathrm{X}_{1}=12 \%, \mathrm{X}_{2}=170{ }^{\circ} \mathrm{C}$, $\mathrm{X}_{3}=180 \mathrm{rpm}, \mathrm{X}_{4}=60 \mathrm{~g} / \mathrm{min} ; \mathrm{f}-\mathrm{X}_{1}=13 \%, \mathrm{X}_{2}=160^{\circ} \mathrm{C}, \mathrm{X}_{3}=195 \mathrm{rpm}, \mathrm{X}_{4}=65 \mathrm{~g} / \mathrm{min} ; \mathrm{g}-\mathrm{X}_{1}=15 \%, \mathrm{X}_{2}=160{ }^{\circ} \mathrm{C}, \mathrm{X}_{3}=165 \mathrm{rpm}, \mathrm{X}_{4}=$ $65 \mathrm{~g} / \mathrm{min} ; \mathrm{h}-\mathrm{X}_{1}=15 \%, \mathrm{X}_{2}=160{ }^{\circ} \mathrm{C}, \mathrm{X}_{3}=195 \mathrm{rpm}, \mathrm{X}_{4}=55 \mathrm{~g} / \mathrm{min} ; \mathrm{i}-\mathrm{X}_{1}=15 \%, \mathrm{X}_{2}=160{ }^{\circ} \mathrm{C}, \mathrm{X}_{3}=195 \mathrm{rpm}, \mathrm{X}_{4}=65 \mathrm{~g} / \mathrm{min} ; \mathrm{j}-\mathrm{X}_{1}=$ $15 \%, X_{2}=180^{\circ} \mathrm{C}, X_{3}=195 \mathrm{rpm}, X_{4}=55 \mathrm{~g} / \mathrm{min} ; \mathrm{k}-\mathrm{X}_{1}=15 \%, \mathrm{X}_{2}=180^{\circ} \mathrm{C}, \mathrm{X}_{3}=165 \mathrm{rpm}, \mathrm{X}_{4}=65 \mathrm{~g} / \mathrm{min} ; \mathrm{l}-\mathrm{X}_{1}=15 \%, \mathrm{X}_{2}=180{ }^{\circ} \mathrm{C}$, $\mathrm{X}_{3}=195 \mathrm{rpm}, \mathrm{X}_{4}=65 \mathrm{~g} / \mathrm{min} ; \mathrm{m}-\mathrm{X}_{1}=14 \%, \mathrm{X}_{2}=170{ }^{\circ} \mathrm{C}, \mathrm{X}_{3}=150 \mathrm{rpm}, \mathrm{X}_{4}=60 \mathrm{~g} / \mathrm{min} ; \mathrm{n}-\mathrm{X}_{1}=14 \%, \mathrm{X}_{2}=170{ }^{\circ} \mathrm{C}, \mathrm{X}_{3}=210 \mathrm{rpm}, \mathrm{X}_{4}=$ $60 \mathrm{~g} / \mathrm{min} ; \mathrm{o}-\mathrm{X}_{1}=14 \%, \mathrm{X}_{2}=170{ }^{\circ} \mathrm{C}, \mathrm{X}_{3}=180 \mathrm{rpm}, \mathrm{X}_{4}=50 \mathrm{~g} / \mathrm{min} ; \mathrm{p}-\mathrm{X}_{1}=14 \%, \mathrm{X}_{2}=170{ }^{\circ} \mathrm{C}, \mathrm{X}_{3}=180 \mathrm{rpm}, \mathrm{X}_{4}=70 \mathrm{~g} / \mathrm{min} ; \mathrm{q}-\mathrm{X}_{1}=$ $14 \%, X_{2}=170{ }^{\circ} \mathrm{C}, X_{3}=180 \mathrm{rpm}, X_{4}=60 \mathrm{~g} / \mathrm{min} ; \mathrm{r}-\mathrm{X}_{1}=15 \%, \mathrm{X}_{2}=160{ }^{\circ} \mathrm{C}, \mathrm{X}_{3}=165 \mathrm{rpm}, \mathrm{X}_{4}=55 \mathrm{~g} / \mathrm{min} ; \mathrm{s}-\mathrm{X}_{1}=13 \%, \mathrm{X}_{2}=180{ }^{\circ} \mathrm{C}, \mathrm{X}_{3}$ $=165 \mathrm{rpm}, \mathrm{X}_{4}=55 \mathrm{~g} / \mathrm{min} ; \mathrm{t}-\mathrm{X}_{1}=13 \%, \mathrm{X}_{2}=180^{\circ} \mathrm{C}, \mathrm{X}_{3}=165 \mathrm{rpm}, \mathrm{X}_{4}=65 \mathrm{~g} / \mathrm{min} ; \mathrm{u}-\mathrm{X}_{1}=13 \%, \mathrm{X}_{2}=180^{\circ} \mathrm{C}, \mathrm{X}_{3}=195 \mathrm{rpm}, \mathrm{X}_{4}=55$ $\mathrm{g} / \mathrm{min} ; \mathrm{v}-\mathrm{X}_{1}=13 \%, \mathrm{X}_{2}=180{ }^{\circ} \mathrm{C}, \mathrm{X}_{3}=195 \mathrm{rpm}, \mathrm{X}_{4}=65 \mathrm{~g} / \mathrm{min} ; \mathrm{w}-\mathrm{X}_{1}=14 \%, \mathrm{X}_{2}=150{ }^{\circ} \mathrm{C}, \mathrm{X}_{3}=180 \mathrm{rpm}, \mathrm{X}_{4}=60 \mathrm{~g} / \mathrm{min}$ and $\mathrm{x}-\mathrm{X}_{1}=$ $14 \%, X_{2}=190^{\circ} \mathrm{C}, X_{3}=180 \mathrm{rpm}, X_{4}=60 \mathrm{~g} / \mathrm{min}$.

Hence, the processing conditions with which these products are obtained can be regarded as the optimum conditions for extrusion of sorghum.

\section{Conclusions}

The present work indicates that sorghum can be extruded to produce ready-to-eat snacks with good organoleptic acceptance. The physicochemical properties and sensory characteristics of sorghum-based extrudate were dependent on process variables, like moisture content, feed rate, screw rpm and barrel temperature. RSM was successfully 
employed to establish the correlation between these process variables and physical properties of extrudates. Feed moisture, barrel temperature and screw speed had significant effect on various physical properties of the extrudate. The effect of feed rate was relatively less. Sensory evaluation of various extrudates has outlined the properties of most favored product. Using the RSM correlations, the combinations of process variables that give varying textural range product were obtained.

\section{Acknowledgments}

The authors are grateful to the Sorghum Research Station (SRS), Marathwada Agricultural University, Parbhani, India, for providing varieties of sorghum for this research work.

\section{References}

[1] A.C. Smith, N. Singh, New applications of extrusion technology, Indian Food Industry 15 (1996) 14-23.

[2] L.A.M. Pelembe, C. Erasmus, J.R.N. Taylor, development of a protein-rich composite sorghum-cowpea instant porridge by extrusion cooking process, Lebensm-Wiss.U. Technol. 35 (2002) 120-127.

[3] N.J. Mesa-Stonestreet, A. Sajid, G. Jeff, Extrusion-enzyme liquefaction as a method for producing sorghum protein concentrates, Journal of Food Engineering 108 (2) (2012) 365-375.

[4] M.H. Gomez, J.M. Aguilera, Changes in the starch fraction during extrusion cooking of corn, Journal of Food Science 48 (1983) 378-381.

[5] M.H. Gomez, J.M. Aguilera, A physicochemical model for extrusion of corn starch, Journal of Food Science 49 (1984) 40-49.

[6] V.J. Davidson, D. Paton, L.L. Diosady, G. Larocque, Degradation of wheat starch in a single screw extruder: Characteristics of extruded starch polymers, Journal of Food Science 49 (1984) 453-458.

[7] C. Mercier, P. Feillet, Modification of carbohydrate component by extrusion cooking of cereal product, Cereal Chemistry 52 (1975) 283-297.

[8] K. Mahasukhonthachat, P.A. Sopade, M.J. Gidley, Kinetics of starch digestion in sorghum as affected by particle size, Journal of Food Engineering 96 (2010) 18-28.

[9] P. Colonna, C. Mercier, Macromolecular modifications of manoic starch components by extrusion cooking with and without lipids, Carbohydrate Polymers 3 (1983) 87-108.
[10] P. Colonna, J.L. Doublier, J.P. Melcion, F. Monredon, C. Mercier, Extrusion cooking and drum drying of wheat starch: I. Physical and macromolecular modifications, Cereal Chemistry 61 (6) (1984) 538-543.

[11] L.F. Wen, P. Rodis, B.P. Wasserman, Starch fragmentation and protein insolubilization during twin screw extrusion of corn meal, Cereal Chemistry 67 (3) (1990) 268-275.

[12] N. Singh, P. Cairns, V.J. Morris, A.C. Smith, Physical properties of extruded wheat starch-additive mixtures, Cereal Chemistry 75 (1998) 325-330.

[13] S.I. Fletcher, P. Richmond, A.C. Smith, An experimental study of twin-screw extrusion cooking of maize grits, Journal of Food Engineering 4 (1985) 291-312.

[14] Association of Official Analytical Chemists (AOAC), Official Methods of AOAC, Volume II, Association of Official Chemists, Washington, 1984.

[15] Association of Official Analytical Chemists (AOAC), Official Methods of AOAC, International, 18th ed., Gaithersburg, MD, USA, 2006.

[16] Association of Official Analytical Chemists (AOAC), Official Methods of AOAC, Volume II, Association of Official Chemists, Washington, 1980.

[17] B. Launay, L.M. Lisch, Twin screw extrusion cooking of starches: Flow behaviour of starch pastes, expansion and mechanical properties of extrudates, Journal of Food Engineering 2 (1983) 259-280.

[18] R.A. Anderson, H.F. Conway, V.F. Pfeifer, E.L. Griffin, Gelatinization of corn grits by roll and extrusion cooking, Cereal Science Today 14 (1969) 4-12.

[19] Vainiopaa, Modelling of extrusion cooking of cereals using Response Surface Methodology, Journal of Food Engineering 13 (1) (1991) 1-26.

[20] W.R. Mason, R.C. Hoseney, Factors affecting the viscosity of extrusion-cooked wheat starch, Cereal Chemistry 63 (1986) 436-441.

[21] A.R. Kirby, A.L. Ollett, R. Parker, A.C. Smith, An experimental study of screw configuration effects in the twin-screw extrusion-cooking of maize grits, Journal of Food Engineering 8 (1988) 247-272.

[22] J.M. Faubion, R.C. Hoseney, High-temperature short-time extrusion cooking of wheat starch and flour: I. Effect of moisture and flour type on extrudate properties, Cereal Chemistry 59(1982) 529-533.

[23] Y. Liu, F. Hsieh, H. Heymann, H.E. Huff, Effect of process conditions on the physical and sensory properties of extruded oat-corn puff, Journal of Food Science 65 (2000) 1253-1259.

[24] G.J. Al-Rabadi, P.J. Tarley, B.A. Williams, W.L. Bryden, M.J. Gidley, Particle size of milled barley and sorghum and physico-chemical properties of grain following extrusion, Journal of Food Engineering 103 (4) (2011) 464-472. 